\title{
小型分散方式による新幹線用空気抵抗ブレーキ装置の開発*
}

\section{Development of Small-Sized Aerodynamic Brake for High-Speed Railway}

\author{
Hajime TAKAMI $^{* 1}$ \\ ${ }^{* 1}$ Railway Technical Research Institute, Vehicle Control Technology Division \\ 2-8-38 Hikari-cho, Kokubunji-shi, Tokyo, 185-8540 Japan
}

There is a strong demand for improving brake system performance of Japanese Shinkansen which is a high speed railway to shorten the stopping distance at the time of an emergency such as a huge earthquake. An emergency brake for conventional train is a wheel disk brake system that is affected by rail tread surface condition (dry or wet condition), because of using friction (adhesion) between a wheel and rail. In order to achieve a high deceleration at the time of over $300 \mathrm{~km} / \mathrm{h}$, another complementary brake system guaranteed a stable braking force without the friction is required. In addition, it has to be a lightweight and small equipment space so that a passenger cabin capacity may not be affected. In this study, we discussed a small-sized aerodynamic brake system using an air drag panel. From the computational fluid dynamics using turbulent flow model and the wind tunnel experiment, the suitable shape of air drag panel, arrangement and an opening-and-closing mechanism of the panel were developed. In addition, a full-scale prototype aerodynamic brake device was designed and manufactured. Its aerodynamic characteristics were examined on a large wind tunnel with high Reynolds number. It was proven that the target braking force can be obtained with the small-sized aerodynamic brake placed into a thick turbulent boundary layer around the train at a running speed of $300 \mathrm{~km} / \mathrm{h}$.

Key Words : Flow Drag, Boundary Layer, Fluid Force, Railway, Air Brake

\section{1. 緒}

新幹線の安全性向上が進む中で，地震等の異常時を考慮して可能な限り緊急時の停止距離を短縮するブレーキ システムが望まれている．現行の新幹線ブレーキシステムは，車輪とつながる駆動用のモータをブレーキとして 利用する電気ブレーキ（電力回生ブレーキ）と，車輪と一体で回転するディスクに摺動材を機械的に押し付ける ディスクブレーキから構成される，これらは，列車の運動エネルギーによる車輪の回転運動を電力や熱などに変 換することで吸収し, 列車を減速させるものである. このとき得られるブレーキ力は，車輪とレールが接触して いる点での接線力と等しくなる.この接線力には車輪に掛かる重量（輪重）や車輪・レールの表面状態によって 限界があり，その上限值は「粘着力」と呼ばれる(1). 粘着力を超えるブレーキ力を作用させた場合，車輪の周速 度のみが減速して車輪は滑走状態となり，列車自体の減速度は十分に得られなくなる．また，粘着力は高速にな るほど低下する特性を有し, 雨天時等はさらに不安定な值を示す (図 1 の参照値).

すなわち，電気ブレーキやディスクブレーキにより得られるブレーキ力は，ブレーキ装置の機械的な性能上限 に加え, 車輪・レール間の粘着力に依存している。したがって, 将来的な新幹線の速度向上に際して安全性を保 つためには，粘着力の制約によるブレーキ力の制限を解決することが必要となる.

一方，このような車輪・レール間の粘着力に依存した「粘着ブレーキ」のほかに，レールへ力を直接作用させ

\footnotetext{
* 原稿受付 2013 年 4 月 16 日

*1 正員，(公財) 鉄道総合技術研究所（广185-8540 東京都国分寺市光町 2-8-38）

E-mail: takami@rtri.or.jp
} 


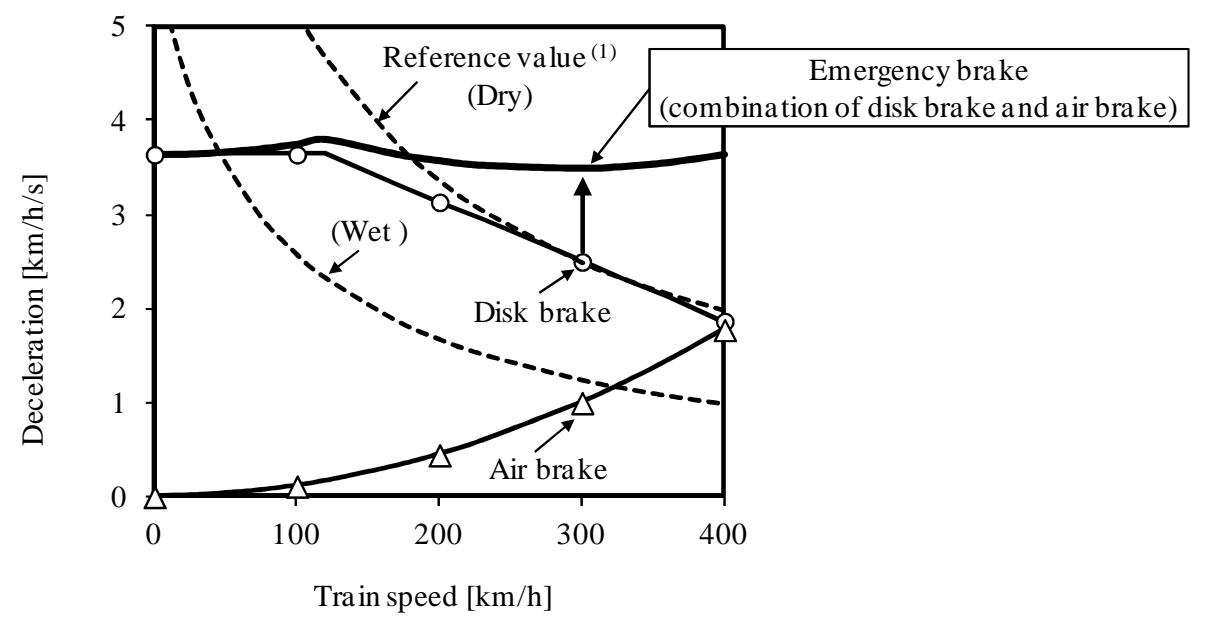

Fig. 1 Deceleration of emergency brake

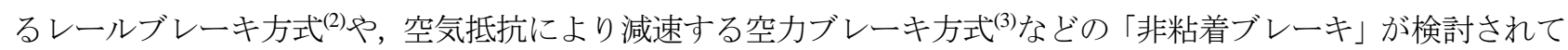
いる．レールブレーキについては，海外の高速鉄道で渦電流方式が既に実用化されているが，台車重量だけでも 1 トン程度の増加が見込まれるほか, 軌道側への影響（レール強度, 信号ノイズ）や電気部品の信頼性, 動作時 の電源確保などの欠点があり，国内の新幹線へ適用するには解決すべき課題が多い.

これに対し，走行風による空気抵抗を利用した空力ブレーキ方式は，比較的軽量で単純な構成が可能であり， 動作時の電源も基本的には不要で信頼性が高い. また，空気抗力は流速の 2 乗に比例して大きくなることから, 粘着ブレーキの高速域を補完する非粘着ブレーキとしては理にかなった方式である. 文献(1)の粘着計画式を基に, 空力ブレーキの想定減速度を加えた減速度設定の一例を図 1 に示寸。このような空力ブレーキは航空機で広く使 われているほか, $500 \mathrm{~km} / \mathrm{h}$ 運転を目指した超電導リニアモーターカー試験車両や, $360 \mathrm{~km} / \mathrm{h}$ 運転を目指した JR 東日本の $\mathrm{E} 954$ 系新幹線試験電車 ${ }^{(4)}$ に搭載された例がある.

本報では，従来よりも大きな抗力（ブレーキ力）が省スペースで得られる新たな鉄道用空力ブレーキ装置の概 要について述べ, 実機相当の試作機を用いた大型風洞試験による性能検証結果について示す.

\section{2. 小型分散方式の空カブレーキ}

\section{$2 \cdot 1$ 従来型空カブレーキの課題}

これまでに開発された鉄道用の空力ブレーキ装置（JR 東日本 E954 系試験搭載品. 以降，従来装置と呼ぶ）を 営業新幹線へ適用寸る場合, 主に以下の 2 点が課題となる.

(a) 現状新幹線の速度域および編成重量では得られる減速度が低い

(b) 空力ブレーキ装置の格納スペースが客室容積を圧迫する

ここで, 空力ブレーキによって得られる減速度 $\beta\left[\mathrm{m} / \mathrm{s}^{2}\right]$ は，一般の空気抵抗式を拡張した次式で表せる.

$$
\beta=\left[\frac{1}{2} \rho_{0} U_{0}^{2} A C_{D} \sum_{i=1}^{n} C_{d 1}(i) \cdot C_{d 2}\right] / M
$$

ただし, 編成における抵抗板の総数を $n$ として, $\rho_{0}$ : 空気密度 $\left[\mathrm{kg} / \mathrm{m}^{3}\right], U_{0}$ : 対気速度 $[\mathrm{m} / \mathrm{s}]$ (走行列車と大気 との相対速度), $A$ : 抵抗板の正面投影断面積 $\left[\mathrm{m}^{2}\right], C_{D}$ : 車両周りの流れ場に設置された抵抗板の抗力係数, $C_{d 1}(i):$ 先頭から $i$ 番目の抵抗板における直列干渉係数（前方の抵抗板による抗力の減少割合，， $C_{d 2}$ : トンネル 係数（トンネル区間において対気速度が増加することによる抗力の増加割合）, $M$ : 編成質量 $[\mathrm{kg}]$ である.

すなわち，走行区間（トンネル，明かり（トンネル以外の区間を指し周囲の空間が閉塞していない状態）） と列 車速度・編成質量などの条件が決められた条件で，課題 (a) の空力ブレーキ減速度を向上するためには，抵抗板 の断面積や総数を増やすか, 1 箇所あたりの抗力係数を増加させる必要がある. しかし, 抵抗板の拡大や総数増 
加は課題 (b) の格納容積縮小と相反する上，車両限界（建築物と支障しない車体断面の限界範囲）の制約や，大 きな抵抗板からのはく離渦による渦励振が走行安定性や架線など地上設備へ与える影響が問題となる. また，従 来装置は抵抗板を車内側へ格納する構成のため, 装置下部が機器スペースとなって設置場所は客室部を除いた車 端部に制約されており（図2(a)参照)，複数台の配置は実質的に困難である.

\section{$2 \cdot 2$ 開発した空カブレーキの概略}

前記課題を解決するため研究を進めた「小型分散方式」は，抵抗板 1 枚あたりの断面積を従来装置よりも逆に 縮小して装置容積の小型化や走行安定性の向上を図ったものである，その一方で，抵抗板の展開機構と抵抗板の 形状を変更して, 抗力係数の増加を図るとともに, 小型・薄型化による設置位置の自由度から直列干渉が最適な 值となるように列車の長手方向へ小型空力ブレーキを分散して配置するものである. この概念を図 2(b)に示す.

ここで, 装置の格納スペースを縮小寸るためには，抵抗板の小型化に加え，抵抗板の展開機構が課題となる. この展開機構は，通常走行中に抵抗板を車両内一格納して車体表面を平滑な状態に保ち，空力ブレーキ装置が抵 抗源や騒音源とならないようにする一方，ブレーキ作動時は抵抗板を速やかに車外へ出して空気抗力を発生させ る機能を有する．このため, 展開機構は小型・軽量であることに加え, 緊急ブレーキ装置としての高い信頼性と 外部電源が断たれた状態での動作が求められる.

このような展開機構として, 抵抗板 2 枚 1 組を無動力・無制御で走行風により作動可能な「トルクバランス展 開機構」を考案した. この概念を図 3 に示す．この駆動方式は，走行風と直交する水平な回転軸周りに 2 枚の抵 抗板を開閉し，2 枚の抵抗板の回転は図中に「バランスギヤ」として示した平歯車により反転動作をさせるもの である. 抵抗板をバネ等のパッシブ機構によりわずかに開くと（開度 $5^{\circ}$ 以下), 列車の進行方向と開き方向によ って助勢力（風圧で開く力）と抗勢力（風圧で閉じる力）を生じるが，2枚の抵抗板によりバランス機構を形成 することで，走行風による開閉方向のトルクは打ち消すことができる. さらに，抵抗板迎え角に着目すると，助 勢側は抗力係数が大きく抗力值が高くなるのに対し, 抗勢側は抗力係数が小さく抗力值は低くなる. 寸なわち, 2 枚の抵抗板に掛かる開閉トルクをバランス機構で差し引きすると, 走行方向に依らず開方向の力が 2 枚の抵抗板 一作用寸る. このため, 走行風がある条件では抵抗板の開動作は無動力・無制御で行われ, その後, 2 枚の抵抗 板は最大開度で保持される. なお，通常走行時は抵抗板が開かないようにするためのロック機構を有する.

走行風を利用したこのような展開機構を小型抵抗板と組み合わせることで, 従来装置と比較して容積比約 $1 / 25$ の小型化と，車体の屋根上搭載可能な薄型化が図られる.

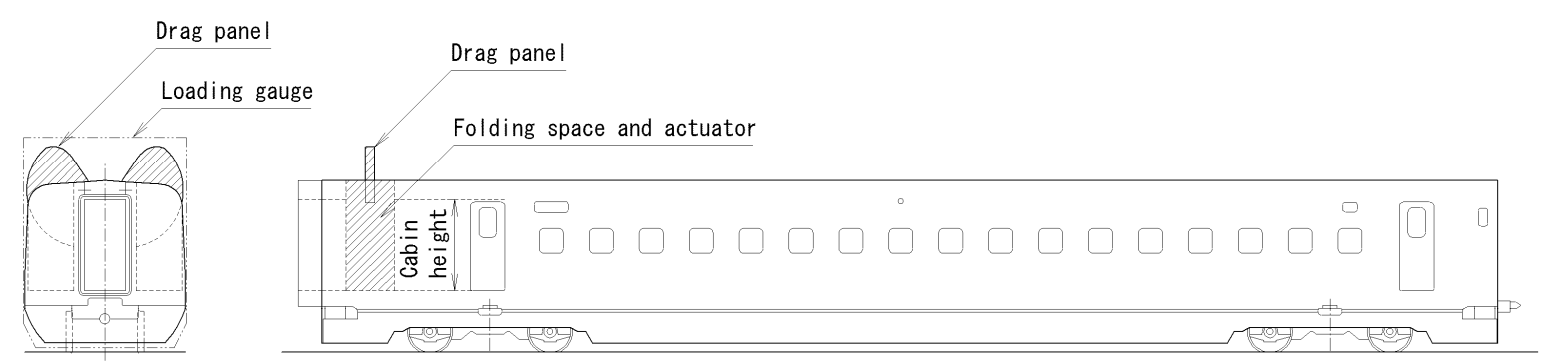

(a) Conventional method
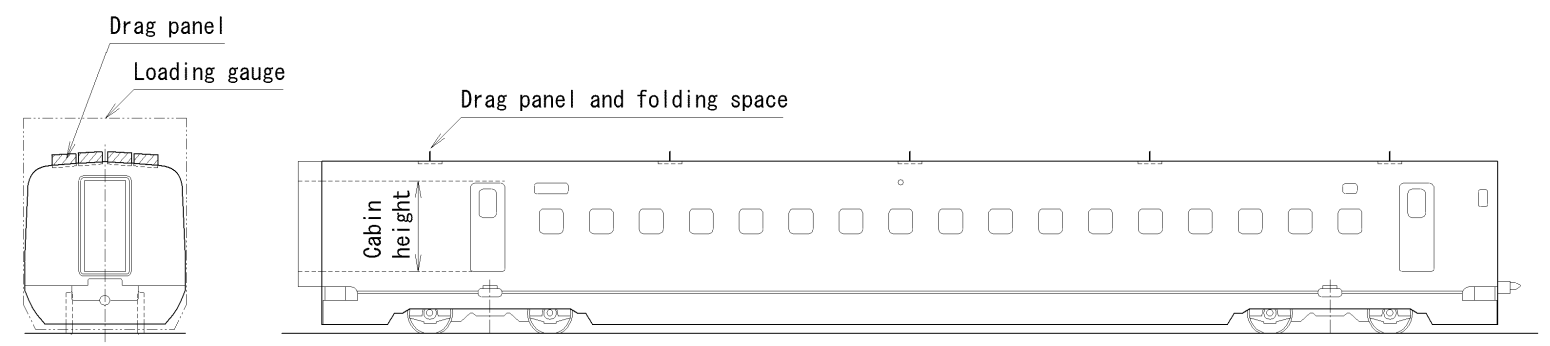

(b) Developed method

Fig. 2 Example of air brake installation 


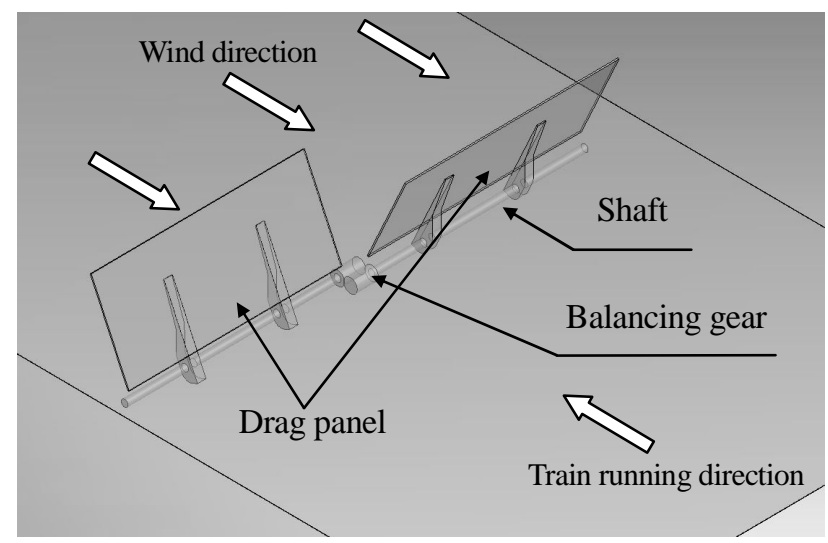

Fig. 3 Schematic of torque balancing mechanism

\section{3. 列車表面の流れ場と抵抗板配置の検討}

\section{$3 \cdot 1$ 前提とした列車周りの流れ場}

通常, 先頭形状に流線形が採用される高速列車においては，先頭部における流れの大きなはく離はなく，列車 の表面に沿って境界層流れが発達する. 流れは，車両先頭における形状変化部の長さ（約 $10 \mathrm{~m} ）$ 以下の速い段階 で臨界レイノルズ数に達しており, 先頭部の局所を除いた下流の車体表面では乱流境界層が発達した状態にある.

このような壁面乱流境界層の詳細については，流れ方向へ極端に長い列車の三次元的な形状から，未だ不明な 点が多い，ただし，台車や集電装置のような凹凸部を除く車体表面を巨視的に平滑とみなし，概ね 2 次元的な平 均流を仮定すれば，床下を除く車体側面および上面に発達する境界層速度分布は，次式の一般的なべキ乗則を用 いて表すことができる.

$$
\frac{u(y)}{U_{0}}=\left(\frac{y}{\delta}\right)^{\frac{1}{n}}
$$

ただし， $\delta$ : 境界層厚さ（車体表面からの高さ $y$ における平均流速 $u$ が主流速度 $U_{0}$ （=列車速度 ）の 99\%に達す る厚さ), $n:$ ベキ指数である.

実際に高速列車周りの流れ場を測定したいくつかの結果から，べキ指数は比較的大きく $n=9 \sim 11$ 程度が推定 されている(5)(6). また，境界層は先頭形状による流れの初期条件および圧力勾配の影響を強く受け，先頭車の早い 段階で急速に厚くなり, その後, 境界層が車体幅の $1 / 3$ 程度に達寸ると, 流れの 3 次元性や 2 次流れの影響を受 けて, 境界層厚さはほぼ一定ないし緩やかな発達傾向をたどる。このとき, 境界層の厚さが最大となる中間車付 近での境界層厚さは, $1 \mathrm{~m}$ 程度と推定されている.

このような車体周りの流れ場中に抵抗板を設置する場合, 境界層の存在によって壁面付近には減速域が存在し ており, 排除厚さ $\delta^{*}$ に相当する距離だけ流れが外側へ排除され, 一様流中に置かれた物体よりも抗力は減少す る.ただし，流れ場としてべキ指数の大きい乱流境界層を前提とすれば，速度分布型は肥えた形状を示し，肥大 した境界層厚さからイメージされるよりも排除厚さは薄く, 抵抗板抗力の減少割合は限定的なものとなる.

\section{$3 \cdot 2$ 抵抗板周りの流れ場の検討}

図 4 は，前提とした壁面乱流境界層中に複数の抵抗板を設置した場合の基礎的な流れ場を，汎用熱流体解析コ ード（ANSYS Fluent）の乱流モデル（RANS）を用いて調べた例である. 解析モデルは，空力ブレーキ装置のう ち，流れ場に影響する抵抗板と補強リブ，および格納部の窪み形状とし，駆動軸やロック機構等についてはモデ ル化を省略した．また，車体断面の正確なモデル化は行わず，中間車両を単純化した形状の屋根上平滑部に空力 ブレーキ装置が埋設される形状である. 計算条件を表 1 に示寸．なお，抵抗板形状はここで示したもの以外に， 高さと幅のほか，板の先端形状と 2 枚 1 組の抵抗板の左右・前後間隔による傾向を調べた．また，抵抗板は計算 


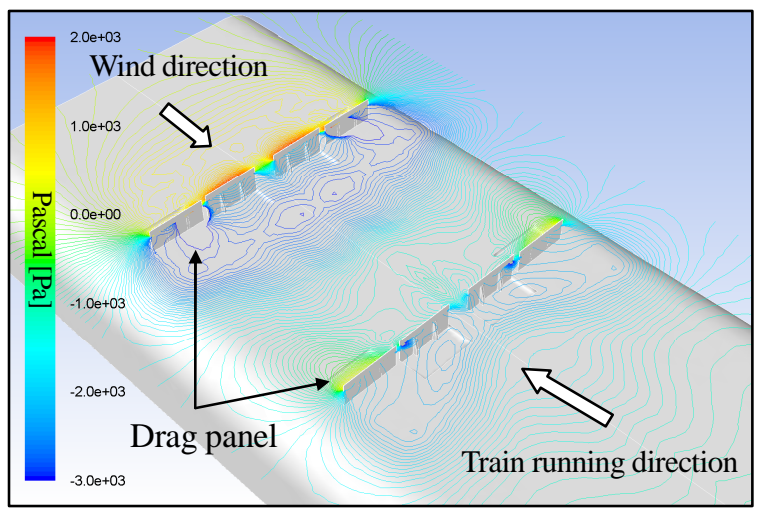

(a) Contours of static pressure

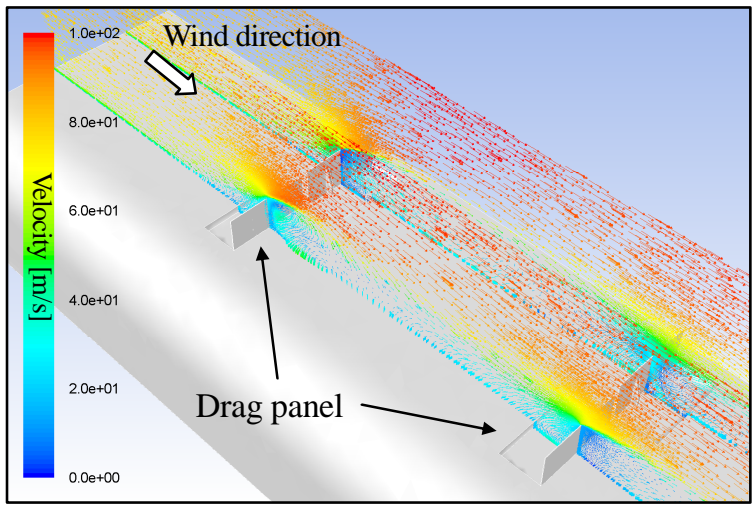

(b) Velocity vectors colored by velocity magnitude
Table 1 Analysis conditions

\begin{tabular}{l|l}
\hline Drag panel & $\begin{array}{l}\text { Rectangular shape } \\
h 0.21 \times w 0.5 \times t 0.003 \mathrm{~m} \\
\text { Interval } r=2.1 \mathrm{~m}(2 \text { lines })\end{array}$ \\
\hline Turbulence model & $\begin{array}{l}\text { Shear-Stress Transport (SST) } \\
\kappa-\omega \text { model }\end{array}$ \\
\hline Inlet condition & $\begin{array}{l}\text { Turbulent boundary layer } \\
\text { velocity profile } \\
\end{array}$ \\
& $\begin{array}{l}U_{0}=83.3 \mathrm{~m} / \mathrm{s}(300 \mathrm{~km} / \mathrm{h}) \\
n=9, \delta=1 \mathrm{~m}\end{array}$ \\
\hline Outlet condition & Pressure outlet boundary \\
\hline number of elements & $2 \times 10^{6}$ (typ.) \\
\hline
\end{tabular}

Fig. 4 Velocity contour

領域内に 8 枚（左右 2 枚を 1 組として 4 台分）を配置した.

この図から,流れは抵抗板前面でせき止められて正圧となる一方, 板背面は流れが剥離することで負圧となり， 板の前後面に圧力差が生じて抗力が発生することが示される．また，前面に衝突した流れは，板前面と壁面との 間に馬蹄形渦を形成して板の側方から下流一流れると同時に，板の上方に跳ね除けられて加速し，板端部から下 流に向けて剥離せん断層を形成する. 板の縦横比がおよそ $1 \leq w / h \leq 5$ の範囲では，一般に板の上端と側端から の剥離せん断層は一体となって板の後方にアーチ渦を形成し(7), より下流における渦の崩壊・拡散とともに壁面 に再付着して，2 枚目以降の抵抗板へ順次作用寸る. 再付着に要する流下距離 $x_{0}$ は，この流れ場ではおよそ $x_{0} / h>6$ の関係があり, それ以降に設置した 2 枚目の抵抗板で発生する抗力は離隔 $r / h$ に依存する.

抗力の大きさは板上端から延びる剥離せん断層とそれにともなう板後方の剥離領域の大きさに相関がある。し たがって，抗力係数は板上端の形状に強く影響を受けるが，板上端を前方に張り出すなどして片側の抗力係数を 増加させても, 点対称形状の反位側抵抗板は板後方の剥離領域が小さくなり, 抗力倸数が減少する. 寸なわち, 2 枚の抵抗板が走行方向に関わらず最大抗力を発生するためには，板上端はシャープエッジで板の最大外形の先端 にあることが適しており，薄板による単純な矩形の抵抗板が製作上優れている．さらに，板の縦横比が小さい場 合 $(w / h<1)$, 板の後方に非対称形のいわゆるカルマン渦列が発生して交番状の渦励振に結び付くことが知られ ており，抵抗板形状として不適当である。

\section{4. 空カブレーキ試作機の性能検証}

\section{$4 \cdot 1$ 試作機の概要}

数值解析および風洞模型実験から小型空力ブレーキ装置として適切な抵抗板形状と配置を決定し，これに基づ いた実機大の概念実証機を試作した．試作機には，抵抗板の展開機構および格納時のロック機構を備えた．試作 機の主な仕様を表 2 に示し, 外観写真を図 5 に示寸. 
Table 2 Specification of air brake prototype

\begin{tabular}{|l|l|c|c|}
\hline \multirow{3}{*}{ Drag panel } & Width of one panel & $w$ & $0.500 \mathrm{~m}$ \\
\cline { 2 - 3 } & Height & $h$ & $0.210 \mathrm{~m}$ \\
\hline \multirow{3}{*}{$\begin{array}{l}\text { Device size at folding } \\
\text { position }\end{array}$} & Length (flow direction) & $0.491 \mathrm{~m}$ \\
\cline { 2 - 3 } & Width & $1.050 \mathrm{~m}$ \\
\cline { 2 - 3 } & Height & $0.050 \mathrm{~m}$ \\
\hline \multirow{2}{*}{ Design load } & Maximum drag force at braking & $2,500 \mathrm{~N}$ \\
\cline { 2 - 3 } & Maximum pressure fluctuation at folding & $\pm 10.8 \mathrm{kPa}$ \\
\hline \multirow{2}{*}{ Process time } & Folding position to braking position & $0.06 \mathrm{sec}$ \\
\cline { 2 - 3 } & Braking position to folding position & $5 \mathrm{sec}$ (nominal value) \\
\hline Weight & & $22.3 \mathrm{~kg}$ \\
\hline
\end{tabular}

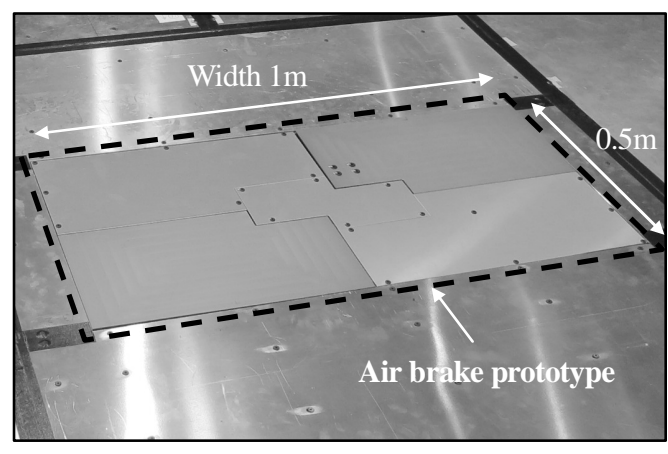

(a) Folding position

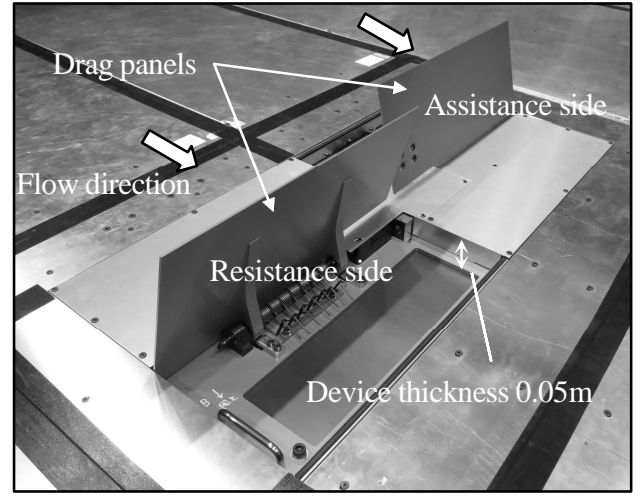

(b) Braking position

Fig.5 Air brake prototype

抵抗板の形状は，走行方向に関わらず適切な抗力が得られる薄板の矩形とし，板の縁部は $\mathrm{C}$ 面を取らず直角と した. 抵抗板の展開方式は，2.2 節に示した「トルクバランス展開方式」とし， 2 枚 1 組の抵抗板で回転卜ルクを 釣り合わせ，走行方向に依らず開動作に必要な動力を不要とした。

作動時の設計荷重 (最大抗力) は, 明かり区間 $400 \mathrm{~km} / \mathrm{h}$ 走行時の抗力推定值にトンネル係数 $C_{d 1}=1.5$ を乗じ(3)(4), さらに過負荷分の余裕を見込んだ $2,500 \mathrm{~N} / 1$ 台とした. この際, 抵抗板の各部に塑性変形等が生じない前提で, 抵抗板には一定の変位を許容する設計である.一方, 空力ブレーキの格納時は抵抗板に抗力はほぼ加わらないが, トンネル走行や対向列車とのすれ違い時に周囲圧力が短い時間で変動し, 閉じた抵抗板の内外に圧力差が生じる ことで, 装置は圧力荷重を受ける，圧力差の大きさは装置の気密度に依存するが，ここでは完全に気密がとられ た条件として, 高速車両の構体と同じ設計条件とした。この際, 負圧方向の力は抵抗板を不用意に開く方向へ作 用するため, これを保持するメカニカルロック機構を構成した.

動作時間は高速走行時の空走距離を左右するため, 極力短くする必要がある. 本方式は外部動力や制御を必要 としないため, 実績で $0.06 \mathrm{~s}$ である. 一方, 格納動作は列車が非常停止した後に時間をおいて格納できればよく, 動作時間の目安として $5 \mathrm{~s}$ 程度とした。 なお，格納操作は内蔵する小型ギヤドモータにより行う.

その他, 特に明示しない寸法・材質については, 機械的な強度を満たす前提において, 装置の小型化・軽量化 に努めた。試作機の実測質量は $22.3 \mathrm{~kg}$ であり, 従来装置と等価なブレーキ力に設定した場合 ( 2 台 $\times 3$ 列配置 $)$, 1 両あたりの装置質量は $134 \mathrm{~kg}$ となる.

なお, 装置表面に段差や不陸はなく (ボル卜頭を除く), 可動部周囲の隙間も $2 \mathrm{~mm}$ 以下とすることで, 格納時 に騒音源となることを防止した。 


\section{4・2 風洞試験条件}

実車両の屋根上流れを模擬した高レイノルズ数の壁面乱流境界層を大型風洞で生成し，その流れ場中に空力ブ レーキ試作機 2 台を設置して性能検証を行った。風洞設備は，(公財）鉄道総研所有の回流型大型低騒音風洞を使 用した．試験の配置概略を図 6 に示し，主な試験条件を表 3 に示寸．なお，表中の $u_{\tau}$ は摩擦速度である.

風洞ノズルは流路断面が大きく特性試験に適したタイプ（～ $83.3 \mathrm{~m} / \mathrm{s}(300 \mathrm{~km} / \mathrm{h}))$ と, 流路断面が小さく高速 流に適したタイプ ( 111.1 m/s $(400 \mathrm{~km} / \mathrm{h}))$ の 2 形式を流速範囲によって使い分け, 各ノズルの最高風速まで試 験を実施した．実車体表面と等価な壁面乱流境界層は，風洞吹き出し口からの助走距離と，風洞吹き出し口の底 面に設置したノコギリ歯状のバリアにより生成し，測定部における壁面乱流境界層の排除厚さを基にしたレイノ ルズ数が実車体表面と等しくなるように調整した（バリア無しで先頭車条件，バリア有りで中間車条件).

抵抗板に働く抗力は, 空力ブレーキ装置をリニアガイドにより前後へ浮動させて設置し, その反力をロードセ ル（東京測器製 CLS-2KNB，定格負荷 $2 \mathrm{kN}$ ）により計測することで行った．合わせて，回転軸のトルクおよび空 カブレーキ装置前後の壁面静圧分布を計測した.

\section{$4 \cdot 3$ 動作特性}

空力ブレーキ動作時の挙動例を図 7(a)に示す. 開指令の投入後 $(t=0)$, 速やかに空力ブレーキが動作し, 慣性 力による著大值が生じた後，抗力（ブレーキ力）が正常に発生している．指令の投入からブレーキ力を生じるま で（平均ブレーキ力に達する最初の時刻まで）の空走時間は 0.06 秒と極めて短く, 高速走行時の緊急ブレーキと して良好な特性を示した.

ここで，反転動作する 2 枚の抵抗板が走行風により開き，その後最大開度で保持されるためには，助勢側の抵 抗板に働く抗力が抗勢側の抵抗板に働く抗力よりも大きくなる必要がある. 寸なわち，2 枚の抵抗板に働く抗力 を差し引きするバランスギヤには，常に開側の軸トルクが残っている必要がある．図 7(b)は抵抗板の開き角度に

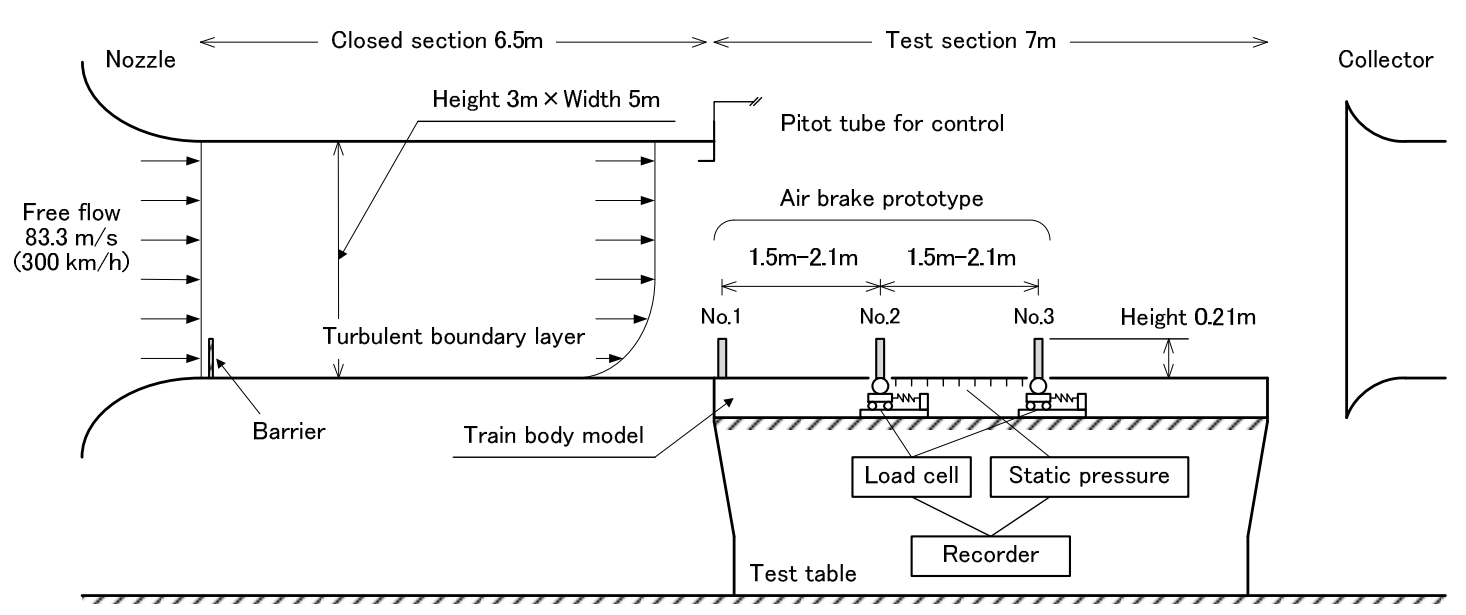

Fig. 6 Layout of experimental apparatus (large nozzle setting illustrated)

Table 3 Experimental condition

\begin{tabular}{|l|c|c|}
\hline \multirow{2}{*}{ Cross section size of wind outlet } & Large nozzle & $5 \mathrm{~m}$ wide $\times 3.0 \mathrm{~m}$ high \\
\cline { 2 - 3 } & Small nozzle & $3 \mathrm{~m}$ wide $\times 2.5 \mathrm{~m}$ high \\
\hline \multirow{2}{*}{ Maximum wind velocity } & Large nozzle & $83.3 \mathrm{~m} / \mathrm{s}(300 \mathrm{~km} / \mathrm{h})$ \\
\cline { 2 - 3 } & Small nozzle & $111.1 \mathrm{~m} / \mathrm{s}(400 \mathrm{~km} / \mathrm{h})$ \\
\hline \multirow{2}{*}{$\begin{array}{l}\text { Inlet condition } \\
\text { (parameter of turbulent boundary layer at } 300 \mathrm{~km} / \mathrm{h})\end{array}$} & - & $h / \delta=1.2, u_{\tau} / U_{0}=0.0300$ \\
\cline { 2 - 3 } Reynolds number & With barrier & $h / \delta=0.26, u_{\tau} / U_{0}=0.0274$ \\
\hline
\end{tabular}




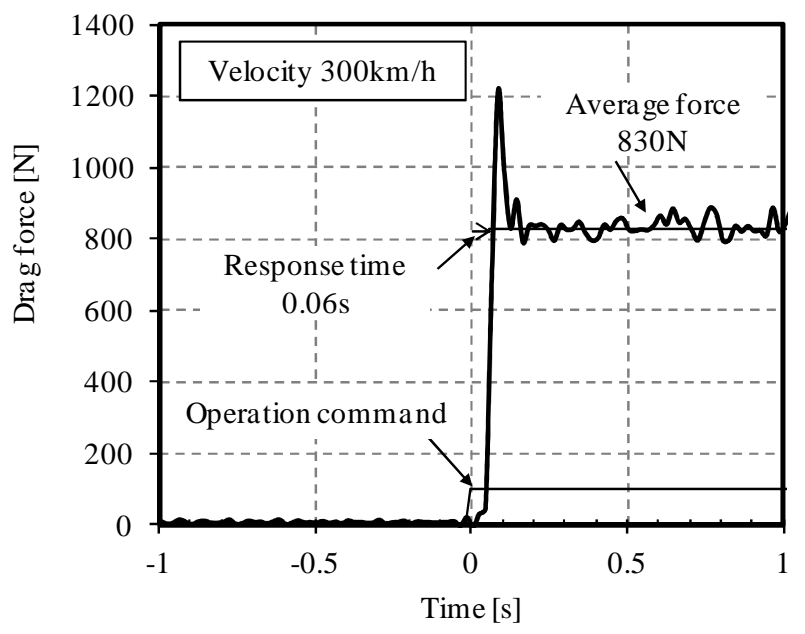

(a) Response time $(h / \delta=1.2)$

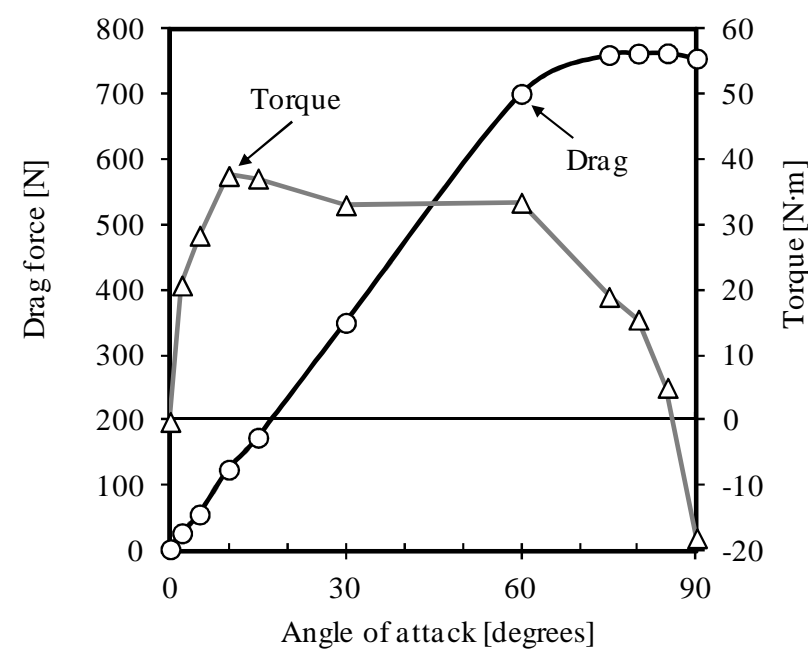

(b) Angle of attack characteristics $(h / \delta=0.26)$

Fig. 7 Characteristics of panel motion

よる特性を調べた結果である。この図から，走行風によるバランスギヤの軸トルクは抵抗板の開度 $2^{\circ}$ で $20 \mathrm{~N} \cdot \mathrm{m}$ （正の符合が抵抗板の開き方向）が得られており，自重による閉じ方向のモーメント（約 $2 \mathrm{~N} \cdot \mathrm{m} ）$ を大きく上回 って，2 枚の抵抗板は俊敏な開き動作が可能となる. また，60以上の開度で開きトルクは徐々に減少するが， $85^{\circ}$ までは開き方向のトルクが残り，90のみ閉じ側に反転する. この際， 2 枚の抵抗板による合計抗力は，各 開度におけるそれぞれの抗力係数と正面投影面積により変化し, 最大抗力は垂直開度のときではなく開度 $75^{\circ} \sim$ 85において得られる.

したがって，抵抗板の最大開度を垂直よりも浅い $75^{\circ} \sim 85^{\circ}$ に設定することで，開きトルクの安定化とブレー キ力確保の両立が可能となる（以降の特性試験結果は最大開度を $75^{\circ}$ に設定した場合）.

\section{$4 \cdot 4$ 抗力特性}

流れ方向へ空力ブレーキを複数台配置した時の 1 台あたりの発生ブレーキ力を図 8(a)に示す. 抗力は主流速度 の 2 乗で増加し, 先頭車条件時の 1 位最大ブレーキ力は $300 \mathrm{~km} / \mathrm{h}$ で $841 \mathrm{~N}, 400 \mathrm{~km} / \mathrm{h}$ で $1,494 \mathrm{~N}$ が実測で得られ ている. また, 2 位以降の装置は上流部位からの直列干渉により得られる抗力が低くなり, 境界層が厚い条件で は壁面近傍の減速域によって得られる抗力はさらに低くなることが示される.

図 8(b)は，抵抗板の高さを流入部の境界層厚さで無次元化し，抗力係数に対する傾向を調べた結果である.た だし, 白丸プロットは垂直平板模型を用いて著者が別途調べた実験值であり, 実線は摩擦速度 $u_{\tau}$ と平板縦横比 $w / h$ に基づき乱流境界層内に埋没する垂直平板の抗力係数を算出する実験式(8)である. この図から，抗力係数は 板の高さと境界層厚さの比に対して指数関数で表され,板の高さが境界層厚さに対して極端に低い場合を除けば, 板を高くしても抗力係数の増加幅はさほど大きなものではない. したがって，抵抗板の高さは実車体周りの流れ 場を考慮して，概ね $0.2<h / \delta<1.0$ の範囲に設定することが装置の小型化には適している.

次に，流れ方向へ空力ブレーキ装置が連続配置される場合，先頭部位が最大の抗力を発生し，第 2 部位以降は 先頭部位からの剥離の影響を受けて抗力が減少する. 先頭部位に対寸る抗力の減少割合 $C_{d 1}(i)$ は, 図 9(a)に示寸 ように抵抗板の離隔 $r$ と高さ $h$ の比に依存し, 前後離隔が短い $r / h<10$ の範囲では空力ブレーキとしての効率は 急激に低下寸るため避ける必要がある．また，第 3 部位の直列干渉は第 2 部位よりも $8 \%$ 程度小さくなるが，こ れは主流が作用する第 1 部位の下流は剥離領域が大きく第 2 部位へ強く影響を与えるのに対し，第 2 部位以降は 一旦剥離した流れが作用するため下流の剥離領域が小さく(抗力が小さく), 下流部位へ与える影響も減少するた めと推測される．なお，試験の都合から第 4 部位以降がないことも第 3 部位の抗力増加には影響しているが， 4 部位を並べて別途実施した縮尺風洞実験から，その影響は3\%程度と見積もられている.

図 9(b)は空力ブレーキ装置前後の壁面静圧分布を調べた結果である. 第 2 部位のみ動作したとき, 第 2 部位か らの流下距離を $x_{0}$ とした下流側 $x_{0} / h<6$ の範囲には, 剥離領域の形成にともなう最大 $-2 \mathrm{kPa}$ 程度の負圧領域が現 


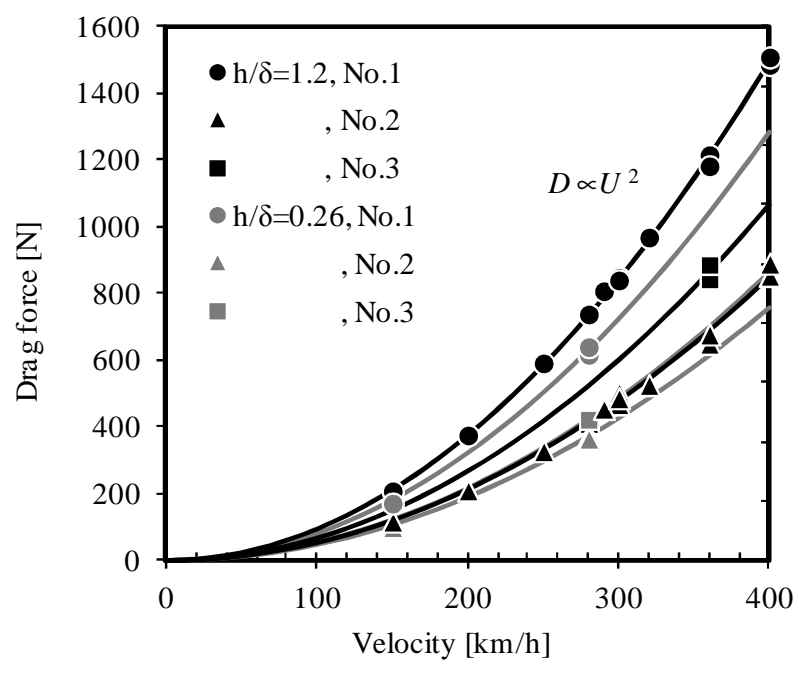

(a) Drag force

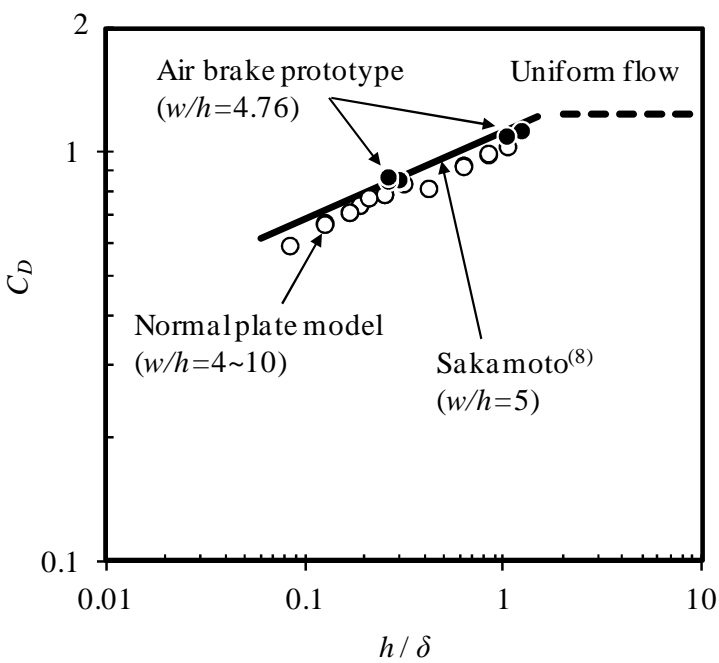

(b) Drag coefficient of single device

Fig. 8 Drag force of air brake prototype

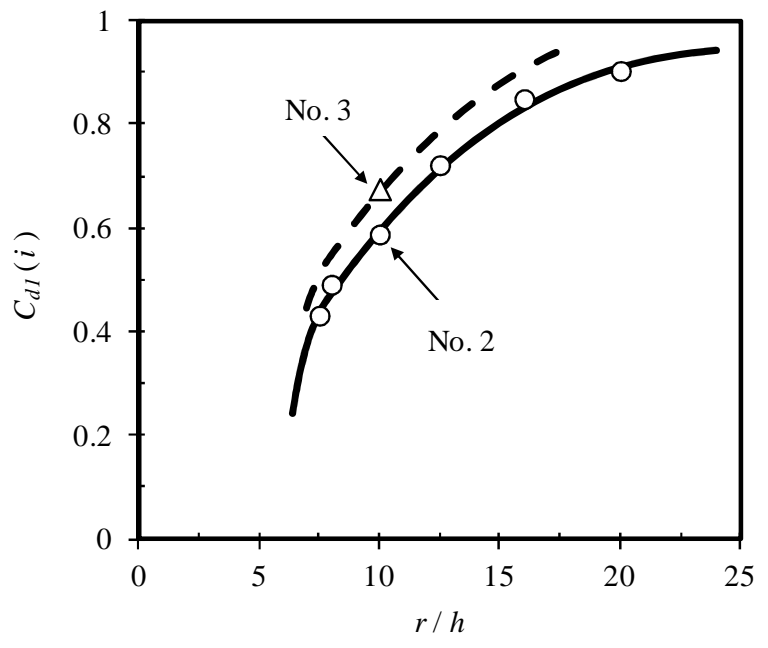

(a) Coefficient of upstream device interference

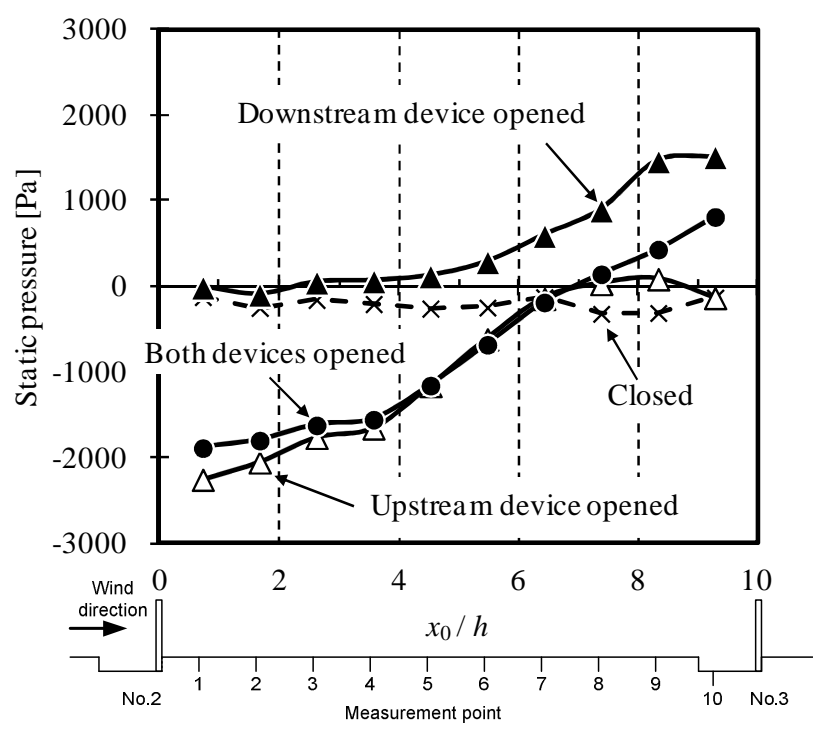

(b) Static pressure distribution

Fig. 9 Interaction of multiple devices at $300 \mathrm{~km} / \mathrm{h}$

れる. 壁面静圧が下流で回復する位置 $\left(x_{0} / h \approx 6\right)$ は，図9(a)の直列干渉が 0 を超える值とも概ね等しく，流れ の再付着点と推測され, 空力ブレーキ装置の前後間隔は最低限それ以上に設定する必要がある.

なお，ブレーキ装置上流側の最大正圧および下流側の最大負圧を $400 \mathrm{~km} / \mathrm{h}$ に換算すると $\left(\Delta p \propto U^{2}\right)$ ，それぞ れ+2.7 kPa, $-4.4 \mathrm{kPa}$ となる. この值は車両構体の気密荷重条件と比較すれば十分小さく, 実車への搭載にあたっ て強度上の問題はない。

\section{$4 \cdot 5$ 空カブレーキによる減速度の評価}

1 編成に空力ブレーキを複数台設置する場合のブレーキ力は, 1 台あたりの抗力係数と前後離隔による抗力の直 列干渉割合, および 1 車体に設置可能な抵抗板の数（=車体長／離隔）によって見積もられる．このため, 装置 の設置数には 1 編成で得られる抗力を最大とする数が存在する.

本実験から推定した $300 \mathrm{~km} / \mathrm{h}$ 走行時における 1 編成分の空力ブレーキ力とその時の減速度を表 4 に示寸. 検討 No.1 は編成のブレーキ力が最大となる設定であり， 1 車体の長手方向へ 10 列を設置し， $300 \mathrm{~km} / \mathrm{h}$ 走行時の減速 
度を約 $1 \mathrm{~km} / \mathrm{h} / \mathrm{s}$ に設定した例である. また, 検討 No.2 は重量やコストを考慮して空力ブレーキの設置数を半減し た例であるが，このときでも従来装置の 1.5 倍に相当する $0.63 \mathrm{~km} / \mathrm{h} / \mathrm{s}$ のブレーキ力が得られると推定される.

Table 4 Estimation of deceleration by small-sized air brakes at $300 \mathrm{~km} / \mathrm{h}$

\begin{tabular}{|c|c|c|c|c|c|c|c|c|}
\hline \multirow[b]{2}{*}{$\begin{array}{c}\text { Study } \\
\text { No. }\end{array}$} & \multirow[b]{2}{*}{ Section } & \multirow{2}{*}{$\begin{array}{r}\begin{array}{c}\text { Interval } \\
\text { of device } \\
(\mathrm{m})\end{array} \\
\end{array}$} & \multicolumn{2}{|c|}{ Number of devices per car } & \multirow{2}{*}{$\begin{array}{l}\text { Number } \\
\text { of cars }\end{array}$} & \multirow{2}{*}{$\begin{array}{l}\text { Weight } \\
\text { of cars } \\
\text { (ton) }\end{array}$} & \multirow{2}{*}{$\begin{array}{l}\text { Brake } \\
\text { force } \\
\qquad(\mathrm{kN})\end{array}$} & \multirow{2}{*}{$\begin{array}{l}\text { Deceleration } \\
\text { of air brake } \\
(\mathrm{km} / \mathrm{h} / \mathrm{s})\end{array}$} \\
\hline & & & $\begin{array}{c}\text { Transverse } \\
\text { direction }\end{array}$ & $\begin{array}{c}\text { Stream-wise } \\
\text { direction }\end{array}$ & & & & \\
\hline \multirow{2}{*}{1} & Open & & & & & \multirow{4}{*}{650} & 186 & 1.03 \\
\hline & Tunnel & 2.5 & 2 & 10 & 16 & & 279 & 1.54 \\
\hline \multirow{2}{*}{2} & Open & \multirow{2}{*}{5.0} & \multirow{2}{*}{2} & \multirow{2}{*}{5} & \multirow{2}{*}{16} & & 115 & 0.64 \\
\hline & Tunnel & & & & & & 173 & 0.96 \\
\hline
\end{tabular}

\section{5. 結 論}

本研究では，空気抵抗を利用した鉄道用の空力ブレーキ装置について，過去に試験研究されたものよりも装置 の小型化と編成全体でのブレーキ力向上が可能な小型分散方式の検討を進めた．検討に基づき，実荷重に対応し た試作機を製作し，列車表面の高レイノルズ数乱流境界層を模擬した大型風洞試験により，無動力での制動動作 と所要のブレーキ力確保が可能であることを示した．本方式の特長をまとめると以下の通りである.

（1）空力ブレーキ装置の小型・薄型化により客室容積を圧迫しない

（2）抵抗板からの放出渦が小さく，高ブレーキ力設定においても走行安定性や地上設備への影響が少ない

（3）動作時の空走時間が短い（実績 0.1 秒以下）

（4）無動力・無制御によるフェイルセーフ動作が可能

今後, 実車搭載に向けて構体構造とのフィッティングや防塵・防水構造, 信頼性の向上などを図る.

\section{謝 辞}

本研究にあたっては，現 JR 北海道・下田氏，現 JR 東海・須山氏，現 JR 西日本・井上氏にそれぞれ試験協力 を頂いた．また，試作機の設計・製作にあたっては，（株）ナブテスコの協力を頂いた．風洞試験にあたっては， 米原風洞センター在勤職員の方々に協力を頂いた．支援いただいた皆様に感謝の意を表する.

\section{文献}

（1）大山忠夫，粘着の話一車輪とレール間の粘着力とその有効利用－(2002), レールアンドテック出版.

(2) 坂本泰明, 柏木隆行, 田中実, 長谷川均, 笹川卓, 藤井信男, “リニア誘導モータを用いた発電制動型レールブレ ーキシステム”, 電気学会論文誌 D, Vol. 129, No. 3 (2009), pp. 342-349.

(3) Yoshimura, M., Saito, S., Hosaka, S. and Tsunoda, H., "Characteristics of the aerodynamic brake of the vehicle on the Yamanashi Maglev test line", Quarterly Report of RTRI, Vol. 41, No. 2 (2000), pp. 74-78.

(4) 新井浩, 菅野悟, 藤野謙司, 加藤博之, 浅野浩二, “新幹線高速化に向けたブレーキの開発”, JR EAST Technical Review, Vol. 31 (2010), pp. 17-21.

(5) Crespi, P., Gregoire, R. and Vinson, P., "Laser doppler velocimetry measurements and boundary layer survey on-board the TGV high speed train", Proc. of the World Congress on Railway Research, (1994).

(6) Takaishi, T. and Ikeda, M., "Experimental method in wind tunnel tests to simulate the turbulent flow on the roof of high-speed trains", Quarterly Report of RTRI, Vol. 53, No. 3 (2012), pp. 167-172.

(7) 岡本史紀, 小林正人, 門野司, 加賀谷春幸, 島根淳, “平面壁上の有限幅直立平板周りの流れ”, 日本機械学会論文 集 B 編，Vol. 71, No. 711 (2005), pp. 2663-2670.

（8）坂本弘志，森谷優，谷口清一，有江幹男，“乱流境界層内に埋没寸る有限幅平板周辺の流れ（第 1 報, 平板に作用 する圧力および抗力)”，日本機械学会論文集 B 編，Vol. 48, No. 433 (1982), pp. 1674-1682. 